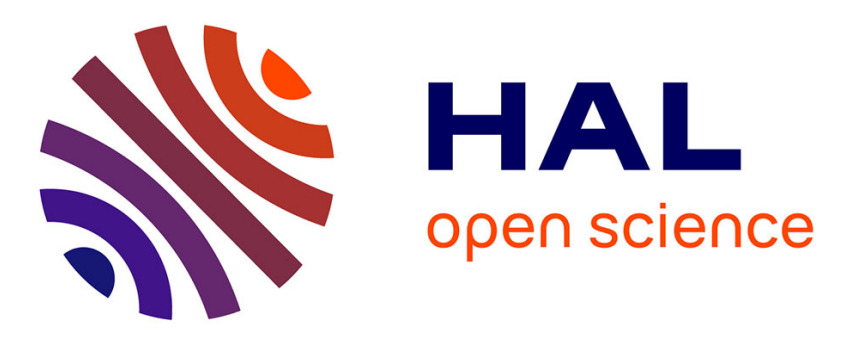

\title{
Structural consequences of dry heating on alpha-lactalbumin and beta-lactoglobulin at $\mathrm{pH} 6.5$
}

Muhammad Gulzar, Said Bouhallab, Julien Jardin, Valérie Briard-Bion, Thomas Croguennec

\section{- To cite this version:}

Muhammad Gulzar, Said Bouhallab, Julien Jardin, Valérie Briard-Bion, Thomas Croguennec. Structural consequences of dry heating on alpha-lactalbumin and beta-lactoglobulin at pH 6.5. Food Research International, 2013, 51, pp.899-906. 10.1016/j.foodres.2013.02.025 . hal-01209406

\section{HAL Id: hal-01209406 \\ https://hal.science/hal-01209406}

Submitted on 29 May 2020

HAL is a multi-disciplinary open access archive for the deposit and dissemination of scientific research documents, whether they are published or not. The documents may come from teaching and research institutions in France or abroad, or from public or private research centers.
L'archive ouverte pluridisciplinaire HAL, est destinée au dépôt et à la diffusion de documents scientifiques de niveau recherche, publiés ou non, émanant des établissements d'enseignement et de recherche français ou étrangers, des laboratoires publics ou privés. 


\title{
Structural consequences of dry heating on alpha-lactalbumin and beta-lactoglobulin at $\mathrm{pH} 6.5$
}

\author{
Muhammad Gulzar ${ }^{\text {a,b,c }}$, Saïd Bouhallab ${ }^{\text {a,b }}$, Julien Jardin ${ }^{\text {a,b }}$, Valérie Briard-Bion ${ }^{\text {a,b }}$, Thomas Croguennec ${ }^{\text {a,b,* }}$ \\ a Agrocampus Ouest, UMR1253 Science et Technologie du Lait et de l'Euf, F-35042 Rennes, France \\ b INRA, UMR1253 Science et Technologie du Lait et de l'Euf, F-35042 Rennes, France \\ c University of Veterinary and Animal Sciences, Abdul Qadir Jilani Road, Lahore, Pakistan
}

\section{A R T I C L E I N F O}

\section{Article history:}

Received 12 December 2012

Accepted 9 February 2013

Available online 24 February 2013

\section{Keywords:}

Alpha-lactalbumin

Dry heating

Dehydration

Pyroglutamic acid

Protein cross-linking

\begin{abstract}
A B S T R A C T
In the present work, we investigated the structural modifications occurring during the dry heating of model whey proteins, $\beta$-lactoglobulin and $\alpha$-lactalbumin. Samples were adjusted to $\mathrm{pH} 6.5$, water activity $\mathrm{a}_{\mathrm{w}}=0.23$ and dry heated at $100{ }^{\circ} \mathrm{C}$ for up to $24 \mathrm{~h}$, and the structural modifications followed by gel permeation chromatography, reverse phase-HPLC, SDS PAGE and mass spectrometry (LC-MS/MS). The dry heating treatment traps a fraction of the proteins into covalently linked soluble aggregates. Moreover, a high proportion of non-aggregated $\alpha$-lactalbumin (about 73\%) was converted into non-native forms. The characteristic of those non-native species was the loss of one or two water molecules per $\alpha$-lactalbumin molecules. Using tandem mass spectrometric peptide mapping, these chemical modifications were found to be attributed to (i) the formation of a pyroglutamic acid from the N-terminal glutamic acid and (ii) the formation of an internal cyclic imide at position Asp 64 . The non-native species were not favored in the case of $\beta$-lactoglobulin as they represented less than $18 \%$ of non-aggregated proteins.
\end{abstract}

(c) 2013 Elsevier Ltd. All rights reserved.

\section{Introduction}

Proteins are widely used as ingredients in food products due to their ability to generate large diversity of textures (e.g. gels, foams, emulsions). Modification of protein structures strongly affects this ability and strategies have been developed to identify safe conditions for generating protein structures with improved functional properties. Dry heating is used in food industry as a mean to modify protein structures leading to improved functional properties (Aoki et al., 1997; Ibrahim, Kobayashi, \& Kato, 1993; Kato, Ibrahim, Watanabe, Honma, \& Kobayashi, 1989, 1990; Matsudomi, Ishimura, \& Kato, 1991). During dry heating, only minor modifications in secondary structures of proteins and a slight increase of accessibility of internal amino acids are observed. In addition dry-heated proteins usually form small soluble aggregates in which proteins are linked together by intermolecular disulfide bonds and also other covalent bonds (Ibrahim et al., 1993; Matsudomi, Takahashi, \& Miyata, 2001; Mine, 1996, 1997). It was hypothesized that improved functional properties can be usually obtained for dry heating conditions leading to aggregates with specific size, structure and reactivity (Kato et al., 1990; Matsudomi et al., 2001; Mine, 1996). However, improved foaming properties have been reported for the dry-heated lysozyme despite the absence of protein aggregation, which in turn may question the contribution of the

\footnotetext{
* Corresponding author at: AGROCAMPUS OUEST, UMR 1253, F-35042 Rennes, France. Tel.: + 33223485927

E-mail address: thomas.croguennec@agrocampus-ouest.fr (T. Croguennec).
}

aggregated forms (Desfougeres, Lechevalier, Pezennec, Artzner, \& Nau, 2008). The racemization of amino acids, the formation of internal cyclic imide, the deamidation of amino acid side chains were all identified as putative structural changes that can explain the enhanced functional properties (Desfougeres, Jardin, Lechevalier, Pezennec, \& Nau, 2010; Matsudomi et al., 2001; Mine, 1997). Dry-heated proteins are less stable (Ibrahim et al., 1993; Desfougeres et al., 2010), which can explain their higher ability to form textures than corresponding native proteins. These structural modifications were mainly observed for egg white proteins dry-heated either under acidic ( $\mathrm{pH} \mathrm{3.5)} \mathrm{or} \mathrm{alkaline} \mathrm{(} \mathrm{pH} \mathrm{8-9)}$ conditions.

Even if dry heating was shown to modify the functional properties of individual whey proteins, beta-lactoglobulin $(\beta-\mathrm{Lg})$ and alphalactalbumin ( $\alpha$-La) (Ibrahim et al., 1993), dry heating of whey proteins under natural $\mathrm{pH}$ conditions, i.e. close to neutral $\mathrm{pH}$, was only slightly studied. Particularly, the molecular basis of the modified functional behavior has not been specifically investigated in that work. More recently, we showed that the gelation property of dry-heated commercial whey protein isolate (WPI) is correlated to the presence of specific type of aggregates (Gulzar, Lechevalier, Bouhallab, \& Croguennec, 2012). However, the complexity of the system (mixture of $\beta-\operatorname{Lg}+\alpha$-La + traces of other proteins) makes a detailed analysis of the structural changes on individual proteins difficult. Our research hypothesis is that understanding the structural and chemical changes that occur during dry heating is the basis for better controlling the functional properties and the reproducibility of dry-heated proteins. In the present study, we focused on the structural modifications that occur during 
the dry heating of the two main whey proteins, $\beta-\operatorname{Lg}$ and $\alpha$-La. $\beta-\operatorname{Lg}$ is a protein of about $18.3 \mathrm{kDa}$ organized mainly in $\beta$-sheets. Its structure contains two disulfide bonds and one free sulfhydryl group inaccessible to solvent under physiological conditions. $\alpha$-La has a predominant $\alpha$-helices structure. It contains 8 cysteine residues, all engaged in disulfide bonds that stabilize the tertiary structure of the protein. Changes in whey protein structure during the dry heating have been investigated at different levels: (i) protein aggregation state, (ii) modifications in secondary and tertiary structures but also (iii) chemical modifications in the primary sequence of the protein. Mass spectrometry (MS and MS/MS) has been used for tracking subtle chemical modifications in the structure of proteins.

\section{Materials and methods}

\subsection{Materials}

$\beta$ - $\operatorname{Lg}$ and $\alpha$-La were obtained from a confidential industrial source. $\beta$-Lg powder contained $93 \%$ protein (determined by Kjeldahl method) of which $90 \%$ of $\beta-\operatorname{Lg}$ (determined by SDS-PAGE), $4.3 \pm 0.2 \%$ moisture and $0.031 \pm 0.002 \%$ calcium, $0.757 \pm 0.038 \%$ sodium, $0.014 \pm 0.001 \%$ potassium, $0.001 \%$ magnesium, $0.066 \pm 0.003 \%$ phosphate, $0.019 \pm$ $0.001 \%$ citrate. $\alpha$-La powder contained $94 \%$ protein (determined by Kjeldahl method) of which $82 \%$ of $\alpha$-La (determined by SDS-PAGE), $3.8 \%$ moisture and $0.067 \pm 0.011 \%$ calcium, $0.95 \%$ sodium, $0.045 \%$ potassium, $0.002 \pm 0.001 \%$ magnesium. No lactose was detected in $\beta$ - $\mathrm{Lg}$ and $\alpha$-La powders. Glycine was from Acros Organics (Geel, Belgium) and all other chemicals were from Sigma Aldrich (Saint-Quentin-Fallavier, France).

\subsection{Preparation of powders and dry heating treatment}

$\beta$-Lg and $\alpha$-La powders were dissolved in distilled water at a protein concentration of $15 \%$ and the protein solutions were adjusted to $\mathrm{pH} 6.5$ prior to freeze-drying. The freeze-dried samples containing $10 \mathrm{~g}$ of proteins were placed for 2 weeks in a desiccator containing saturated salt $\left(\mathrm{CH}_{3} \mathrm{CO}_{2} \mathrm{~K}\right)$ solution to reach an $\mathrm{a}_{\mathrm{w}}$ of 0.23 . The $\mathrm{a}_{\mathrm{w}}$ of the freezedried protein powders was checked by $\mathrm{a}_{\mathrm{w}}$ meter (Novasina RTD 200/0 and RTD 33, Pfäffikon, Switzerland). Values of $\mathrm{pH}$ and $\mathrm{a}_{\mathrm{w}}$ were chosen close to those found in the commercial spray dried powders. Freezedried protein powders $\left(a_{w} 0.23\right)$ were heated at $100{ }^{\circ} \mathrm{C}$ for 8,16 and $24 \mathrm{~h}$ in hermetically sealed bottles. A sample was kept unheated (reference sample). Each sample was prepared in duplicate.

\subsection{Samples preparation}

\subsubsection{Total protein}

Powders (unheated and dry-heated) were reconstituted at $10 \mathrm{~g} / \mathrm{L}$ in $0.12 \mathrm{M} \mathrm{NaCl}$ solution. The $\mathrm{pH}$ was adjusted to 7 by addition of $1 \mathrm{~N} \mathrm{NaOH}$.

\subsubsection{Non-aggregated proteins}

A volume of $200 \mu \mathrm{L}$ of $0.5 \mathrm{M}$ acetic acid/sodium acetate buffer ( $\mathrm{pH} 4.5$ or $\mathrm{pH} 4.7$ for $\alpha$-La and $\beta$ - $\mathrm{Lg}$ respectively) was added to $1000 \mu \mathrm{L}$ of total protein samples (Section 2.3.1). The mixture was placed in a water bath equilibrated at $30{ }^{\circ} \mathrm{C}$ for 1 min for precipitating aggregated proteins. The mixture was then centrifuged at 10,000 $\mathrm{g}$ for $15 \mathrm{~min}$ using an Eppendorf 5415C Micro Centrifuge (Scientific Support, Hayward, California). The supernatant containing non-aggregated proteins was recovered.

\subsubsection{Protein hydrolysis}

For tryptic digestion, a volume of $10 \mu \mathrm{L}$ of $100 \mathrm{mM}$ dithiothreitol (DTT [Pharmacia Biotech, France] in $50 \mathrm{mM}$ Tris-HCl buffer $\mathrm{pH} 8.5$ containing $6 \mathrm{M}$ urea) was added to $1 \mathrm{~mL}$ of $\beta$-lg and $\alpha$-La samples (unheated and dry-heated) prepared at $1 \mathrm{~g} / \mathrm{L}$ in a $50 \mathrm{mM}$ Tris- $\mathrm{HCl}$ buffer pH 8.5 containing $6 \mathrm{M}$ urea. The reduction was carried out at
$56{ }^{\circ} \mathrm{C}$ for $1 \mathrm{~h}$. After reduction, $40 \mu \mathrm{L}$ of iodoacetamide (IAA) at $2 \mathrm{M}$ was added to the solution and the mixture was incubated at room temperature in the dark. The solutions were dialyzed overnight against a $10 \mathrm{mM}$ sodium bicarbonate buffer at $\mathrm{pH} 8.5$ to remove excess reagents. A stock solution of $1 \mathrm{~g} / \mathrm{L}$ trypsin was added to the dialyzed sample to have an enzyme/protein weight ratio of 1:100. The solutions were hydrolyzed at $37{ }^{\circ} \mathrm{C}$ for $2 \mathrm{~h}$. The hydrolysis was stopped by decreasing the pH below 3 with trifluoroacetic acid (TFA).

For peptic digestion, $\alpha$-La (unheated and dry-heated) was diluted at $4 \mathrm{~g} / \mathrm{L}$ in a $20 \mathrm{mM}$ phosphate buffer containing $8 \mathrm{M}$ urea ( $\mathrm{pH} 4.5$ ) and $4.2 \mathrm{mM}$ tris(2-carboxyethyl)phosphine (TCEP) for reduction, which is an efficient reducing agent under acidic $\mathrm{pH}$ condition. After $1 \mathrm{~h}$ at room temperature, the solution was diluted $1 / 4$ in a $100 \mathrm{mM}$ $\mathrm{HCl} / \mathrm{KCl}$ buffer $\mathrm{pH} 1.0$. $\alpha$-La proteolysis was triggered by adding $50 \mu \mathrm{L}$ of pepsin $(170 \mu \mathrm{M}$ in a $100 \mathrm{mM} \mathrm{HCl} / \mathrm{KCl}$ buffer $\mathrm{pH} 1.0)$ to $200 \mu \mathrm{L}$ of protein solution. After $5 \mathrm{~h}$ a second addition of $50 \mu \mathrm{L}$ pepsin was performed to complete the proteolysis.

\subsection{Samples analysis}

\subsubsection{Gel permeation chromatography}

Proteins were analyzed by High Pressure-Gel Permeation Chromatography (HP-GPC) using a TSK G3000 SWXL $(300 \times 7.8 \mathrm{~mm}$ i.d.) column (Phenomenex, Le Pecq, France) connected to a Waters chromatography system (Milford, USA), consisting of a Waters 2695 Separation Module, a Waters 2487 Dual $\lambda$ Absorbance Detector and a Empower chromatography application software to acquire, process and report chromatographic information. A phosphate buffer $0.05 \mathrm{M}, \mathrm{pH} 7$ containing $0.1 \mathrm{M} \mathrm{NaCl}$ was used to equilibrate the column and to elute the proteins at a flow rate of $0.8 \mathrm{~mL} / \mathrm{min}$. Proteins were detected at $214 \mathrm{~nm}$. The percentage of non-aggregated proteins in the sample was calculated from the ratio between the chromatographic peak area of non-aggregated proteins and total chromatographic peak area; the percentage of aggregated proteins was calculated by difference.

\subsubsection{Reverse phase chromatography}

Proteins were analyzed by reverse phase-HPLC on a Vydac C4 connected to the HPLC system described above (Section 2.4.1). The column was equilibrated with $59 \%$ of solvent A (milli-Q water containing $1.06 \%$ 。 $(\mathrm{v} / \mathrm{v})$ trifluoroacetic acid) and $41 \%$ solvent B (HPLC grade-acetonitrile:Milli-Q water $(80: 20, \mathrm{v} / \mathrm{v})$ mixture containing $1 \%$ (v/v) trifluoroacetic acid). A linear gradient started with $41 \%$ of solvent B to reach $61 \%$ over 24 min was used for protein elution. Protein separation was carried out at $40{ }^{\circ} \mathrm{C}$ at a flow rate of $0.2 \mathrm{~mL} / \mathrm{min}$. Proteins were detected at $214 \mathrm{~nm}$.

\subsubsection{SDS-PAGE analysis}

SDS-PAGE was performed under reducing (with DTT) and nonreducing conditions (without DTT) using a Mini Protean II system (Bio-Rad Laboratories, A Technologies, Dublin, Ireland) as described by Laemmli (1970) using 15\% acrylamide separating gel and $4 \%$ concentration gel. Protein samples were diluted 10 folds with the denaturing buffer (77.975\% 0.08 M Tris-HCl pH 6.8; 20\% glycerol; 2\% SDS; 0.025\% bromophenol blue). $10 \mu \mathrm{g}$ of proteins was loaded in the sample slots and was separated at $75 \mathrm{~V}$ for $30 \mathrm{~min}$ and then at $150 \mathrm{~V}$ for $60 \mathrm{~min}$. Gels were stained with Coomassie Brilliant Blue G250. A low molecular weight marker kit (14.4-94 kg/mol, Amersham Biosciences, France) was used for molecular weight (MW) calibration. The gels were scanned by Image Scan II (Amersham, Bioscience). The percentage of $\beta$ - $\operatorname{Lg}$ and $\alpha$-La monomers in the samples was quantified from the SDS-PAGE performed in the absence of DTT using densitometry software, Image Quant TL 1D (Amersham, Bioscience).

\subsubsection{Mass spectrometry}

Mass spectrometry analyses were carried out on a hybrid quadrupole time-of-flight (Q-TOF) mass spectrometer QStar XL (MDS Sciex, 
Toronto, Canada). When the entire mass of polypeptides was investigated, experiments were performed by direct infusion electrospray ionization mass spectrometry (ESI-MS) using a nano ESI sample source. Data were collected and processed using Analyst QS 1.1 Sciex software, and the deconvolution of spectra was carried out using Bioanalyst 1.1.5. Analysis of the hydrolytic peptides was performed by reverse-phase HPLC separation using a nano-LC system equipped with a PepMap C18 column $(3 \mu \mathrm{m}, 100 \AA, 75 \mu \mathrm{m}$ i.d. $\times 250 \mathrm{~mm})$ and coupled to the mass spectrometer. Peptides were separated using a linear gradient of solution A ( $2 \% \mathrm{ACN}, 0.08 \%$ formic acid, $0.01 \%$ trifluoroacetic acid (TFA)) and B (95\% ACN, $0.08 \%$ formic acid, $0.01 \%$ TFA) from 5 to $40 \%$ of solution B in $65 \mathrm{~min}$. A voltage of $3000 \mathrm{~V}$ was applied to the nanoelectrospray ion source (Proxeon Biosystems A/S, Odense, Denmark). A full continuous MS scan was carried out, followed by three data-dependent MS/MS. The first, second, and third most intense ions from the MS scan were selected individually for collision-induced dissociation. The mass spectrometer was operated in data-dependent mode, automatically switching between MS and MS/MS acquisition using Analyst QS 1.1 software.

Mass spectrometry analysis on a QSTAR XL Q/TOF spectrometer gives a mass resolution of 10,000 , therefore giving a precision of \pm 1 Da on entire proteins mass measurement and \pm 0.1 Da on peptides.

\section{Results}

\subsection{Dry heating induces whey proteins aggregation}

The dry-heating induced aggregation of whey proteins ( $\beta$ - $\mathrm{Lg}$ and $\alpha$-La) was investigated by High performance-gel permeation chromatography (HP-GPC) and SDS-PAGE.

Fig. 1 shows the HP-GPC profile of unheated and dry-heated ( $24 \mathrm{~h}$ at $100{ }^{\circ} \mathrm{C}$ ) samples of $\beta$-Lg (Fig. 1a) and $\alpha$-La (Fig. 1b) at pH 6.5. For unheated $\beta$-Lg, the major peak eluted at $12.2 \mathrm{~min}$ was assigned to a non-aggregated $\beta$-Lg; it represented $92 \pm 5 \%$ of the total protein content. From its solubility criteria at $\beta-\operatorname{Lg} p I$, the non-aggregated $\beta-\mathrm{Lg}$ was considered as a native monomer/dimer equilibrium of $\beta$ - Lg. A small amount of oligomers, mainly dimers and trimers, eluting between 10 and 11.5 min and representing around $10 \%$ of the total proteins, was also detected in the unheated sample. The unheated samples of $\alpha$-La showed one major peak eluted at $12.9 \mathrm{~min}$, which corresponded to the non-aggregated $\alpha$-La (monomer) and represented about $87 \%$ of the total proteins. In addition a small amount (13\%) of oligomers and a contaminant $\beta$ - $\mathrm{Lg}$ was also present; they were eluted between 10 and $12 \mathrm{~min}$. The dry heating induced a significant decrease of the non-aggregated $\beta$ - $\mathrm{Lg}$ and $\alpha$-La (reduction of the chromatographic peak area) and a simultaneous increase of the amount of oligomers. The percentage of the non-aggregated $\beta$ - $\operatorname{Lg}$ and $\alpha$-La was $65 \pm 5 \%$ and $73 \pm 5 \%$, respectively, after $24 \mathrm{~h}$ of dry heating. The aggregated proteins that precipitated close to the corresponding protein $\mathrm{pI}$ were fully soluble at neutral $\mathrm{pH}$.

The interactions involved in the aggregates formed during the dry heating were further characterized by SDS-PAGE in the absence or presence of reducing agent (DTT) (Fig. 2). SDS-PAGE analysis in the absence of the reducing agent (Fig. 2a and c) confirms the HP-GPC quantifications: The proportion of the non-aggregated $\beta-\mathrm{Lg}$ and $\alpha-\mathrm{La}$ was $66 \%$ and $74 \%$ respectively, after $24 \mathrm{~h}$ of dry heating versus $89 \%$ and $87 \%$ in the unheated reference samples. Since HP-GPC preserves covalent and noncovalent interactions and SDS PAGE preserves only the covalent ones, we deduced from the above results that both $\beta-\mathrm{Lg}$ and $\alpha$-La aggregates were mainly linked together by covalent bonds. Oligomers of $\beta$ - $\mathrm{Lg}$ and $\alpha$-La observed in the unheated samples in the absence of reducing agent, disappeared under the reducing conditions (i.e. in the presence of DTT, Fig. 2b and d). In contrast, some aggregated forms (especially dimers of $\beta-\mathrm{Lg}$ and dimers of $\alpha$-La) observed in the dry-heated samples were resistant to reduction. In addition, the $\alpha$-La sample contained a small amount of non-aggregated $\beta$-Lg. In
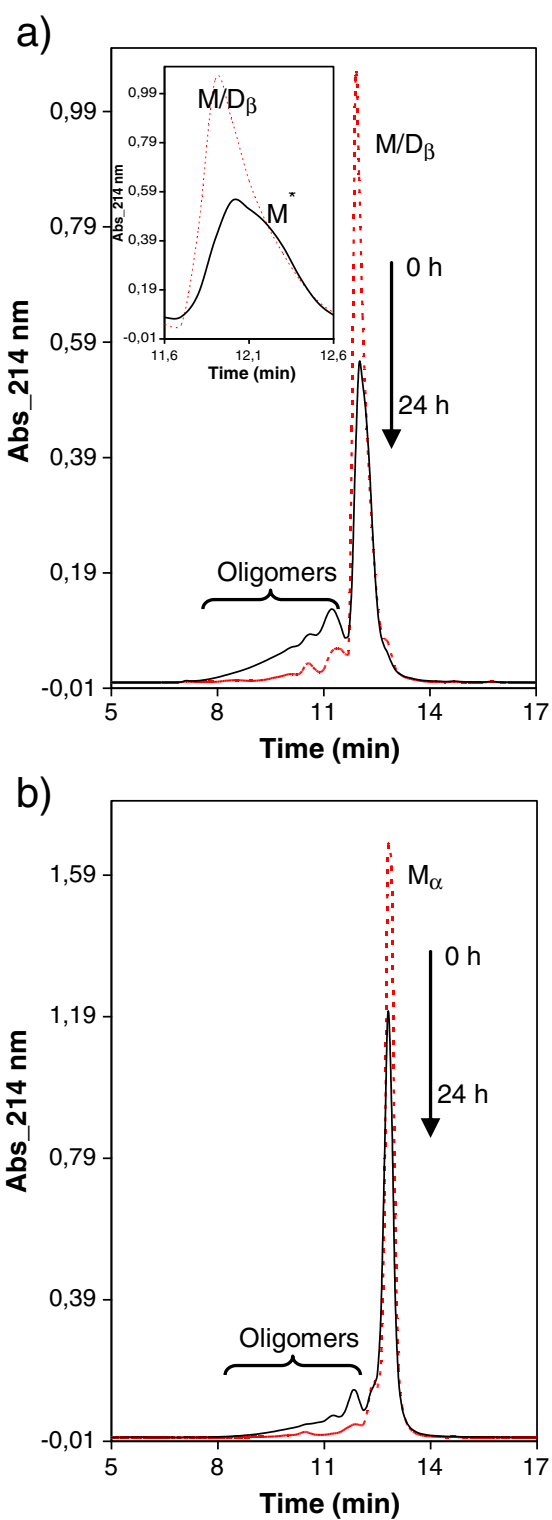

Fig. 1. HP-GPC profile of $\beta$-lactoglobulin (1a) and $\alpha$-lactalbumin (1b) samples before (reference sample, dotted line) and after (full line) dry heating treatment at $100{ }^{\circ} \mathrm{C}$, $24 \mathrm{~h} . \mathrm{M} / \mathrm{D}_{\beta}$ corresponds to native monomer/dimer equilibrium of $\beta$-lactoglobulin, while $M_{\alpha}$ corresponds to the monomer of $\alpha$-lactalbumin. Inset (1a): zoom of the chromatographic peaks corresponding to non-aggregated $\beta$-lactoglobulin, where $\mathrm{M}^{*}$ represents the non-native monomers of $\beta$-lactoglobulin.

the absence of DTT, the intensity of the electrophoretic band of non-aggregated $\beta$-Lg decreased slightly with the dry heating time but it was recovered after sample reduction.

\subsection{Changes in the structure of dry-heated whey proteins}

The secondary structure of the whey proteins was determined on unheated and dry-heated powders by Fourier Transformed Infrared Spectroscopy (FTIR). For both proteins, no change in FTIR spectra was detected during the course of dry heating (see Supporting information, Fig. S1). The same powders (reconstituted in solution at $\mathrm{pH} 7$ ) analyzed by near-UV circular dichroism for identifying changes in the tertiary structure of the proteins exhibited only a slight decrease in the spectra intensity; the intensity decrease was $17 \%$ for $\beta$ - $\mathrm{Lg}$ and $25 \%$ for $\alpha$-La after $24 \mathrm{~h}$ of dry heating and was attributed to protein aggregation (see Supporting information, Fig. S2). 


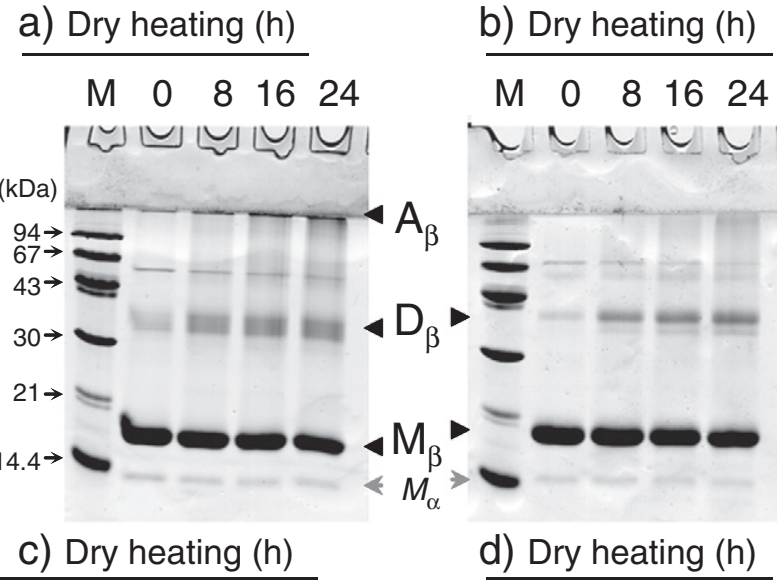

$\begin{array}{llllll}M & 0 & 8 & 16 & 24\end{array}$

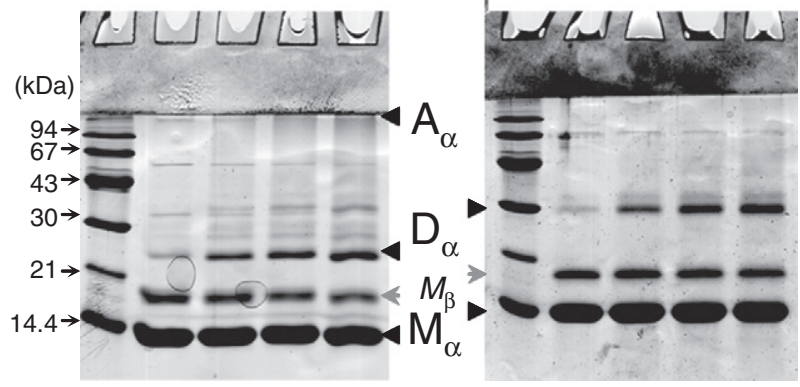

Fig. 2. SDS-PAGE profile in the absence $(a, c)$ and presence $(b, d)$ of reducing agent DTT of $\beta$-lactoglobulin (a,b) and $\alpha$-lactalbumin (c, d) samples before ( 0 ) and after 8, 16 and $24 \mathrm{~h}$ of dry heating treatment at $100{ }^{\circ} \mathrm{C}$. M, low molecular weight markers; $A_{B}$, $D_{\beta}, M_{\beta}$ represents aggregates, dimers and monomers of $\beta$-lactoglobulin; $A_{\alpha}, M_{\alpha}, D_{\alpha}$ represents the aggregates, dimers and monomers of $\alpha$-lactalbumin.

The HP-GPC profile of the dry-heated $\beta$-Lg indicated that the peak of non-aggregated $\beta$-Lg was shifted to right during the dry heating, revealing a displacement of the dimer/monomer equilibrium towards the monomeric form (inset in Fig. 1a). The dry heating treatment did not affect the retention time of $\alpha$-La (HP-GPC, Fig. 1) but a distinctive change in the reverse phase chromatography profile of the non-aggregated $\alpha$-La (soluble fraction at the protein $p I$ ) was detected (Fig. 3). The chromatographic peak eluted at 19 min corresponding to the non-aggregated native $\alpha$-La ( $\mathrm{M} \alpha$ in Fig. 3) progressively decreased during the dry heating and a new, more hydrophobic molecular species eluted at 20 min was formed ( $\mathrm{M} \alpha^{*}$ in Fig. 3). In contrast to the aggregates, these non-aggregated species of $\beta$ - $\mathrm{Lg}$ and $\alpha$-La were soluble close to the corresponding protein $\mathrm{pI}$.

The mass spectrometry analysis of the non-aggregated fraction of $\alpha$-La (soluble fraction at the protein $p I$ ) exhibited irreversible mass loss of 18 Da or 35 Da per molecule after the dry heating treatment (Fig. 4). Based on the resolution of the mass spectrometry (see Materials and methods section) these mass losses could be assigned either to the release of one and two water molecules per protein, one and two ammonia molecules per protein or a combination of these two possibilities. The molecular mass of the predominant molecular species in unheated sample of $\alpha$-La was $14,180 \pm 1 \mathrm{Da}$ (Fig. 4a), corresponding to the molecular mass of native $\alpha$-La. Strikingly, a significant fraction of non-aggregated $\alpha$-La molecule (16\%) was detected at $14,162 \pm 1 \mathrm{Da}$ and exhibited also a mass loss of $18 \mathrm{Da}$. The dry heating treatment increased the proportion of the $\alpha$-La molecules that exhibited mass losses (Fig. 4b) as $73 \pm 4 \%$ of the non-aggregated $\alpha$-La exhibited a mass loss of $18 \mathrm{Da}$ or $35 \mathrm{Da}$ after 24 h of dry heating.

The sites of modification (dehydration and/or deamidation) of $\alpha$-La molecules were tracked using the tryptic digest of the protein. The tryptic

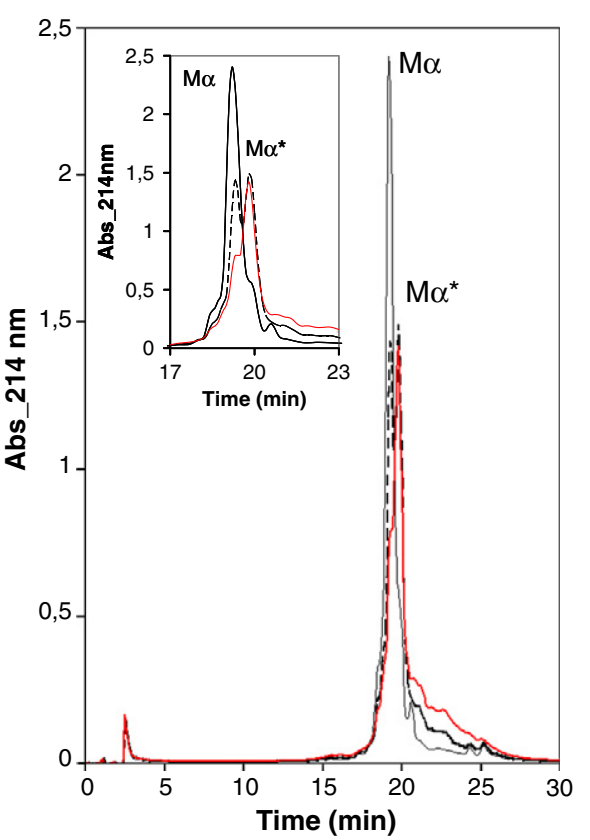

Fig. 3. Reverse phase-HPLC of the non-aggregated $\alpha$-lactalbumin (soluble fraction at protein $\mathrm{pI}$ ) before (full thin line) and after 8 (dotted line) and $24 \mathrm{~h}$ (full thick line) of dry heating treatment at $100{ }^{\circ} \mathrm{C} . \mathrm{M}_{\alpha}$ and $\mathrm{M}_{\alpha}{ }^{*}$ correspond to native and non-native monomers of $\alpha$-lactalbumin. Inset: zoom on the chromatographic peak of non-aggregated $\alpha$-lactalbumin.

digest was analyzed by reverse phase NanoLC coupled with ESI MS/MS Based on the primary sequence of $\alpha$-La and the trypsin specificity, the tryptic peptides were identified according to their MW and MS/MS spectra. Manual inspection of MS/MS spectra was performed for peptides presenting a mass difference $\Delta_{\mathrm{MW}}=\mathrm{n} \times(-18 \mathrm{Da})+\mathrm{m} \times(-17 \mathrm{Da})$ from the expected MW, with $\mathrm{n}$ and $\mathrm{m}$ natural numbers taking values of 0,1 or 2 (no protein molecule with total modifications $m+n>2$ was detected, Fig. 4). The localization and the type (dehydration or deamidation) of the first modification of the dry-heated $\alpha$-La were clearly identified by comparing the tryptic digest of the dry-heated and the unheated reference sample of $\alpha$-La. In fact, the intensity of the N-terminal peptide EQLTK (618.3 Da) decreased in the tryptic digest of dry-heated $\alpha$-La. Concomitantly, an increase in the peak intensity at the mass 600.3 Da (N-terminal peptide EQLTK minus $18 \mathrm{Da}$ ) was observed. The sequencing of this peptide by MS/MS indicated that the modification occurred to the N-terminal residue E (Fig. 5) and corresponded to the release of one molecule of water. In contrast, the localization of the second site of modification was not so obvious. The mass spectrometry profile of the $\alpha$-La tryptic digest indicated that the intensity of the native peptide 63-79 (2002.8 Da) was reduced by a factor higher than 2 after $24 \mathrm{~h}$ of dry heating, but regardless of the type of the $\alpha$-La sample (unheated or dry-heated) any corresponding modified peptide that would exhibit a mass loss was not detected. The absence of the tryptic peptide 63-79 exhibiting a mass loss of $18 \mathrm{Da}$ could be the result of a modification of one amino acid located close to the site recognized by trypsin (Fig. 6). In order to confirm this assumption and that the mass loss was not due to a rearrangement of the peptide during the hydrolysis of $\alpha$-La by trypsin, a pepsin digestion was analyzed using the same protocol. A mass loss was detected on the sequence 54-71 (Fig. 6). The native peptide 54-71 (2140.0 Da) was recovered in both samples (unheated and dry-heated) but the intensity of the modified peptide of $2122.0 \mathrm{Da}$ (mass of the peptide 54-71 minus $18 \mathrm{Da}$ ) was five-fold greater after the dry heating. Once again, the mass loss was assigned to the release of one water molecule. The only residues that might release one molecule of water in the sequence 54-71 were $D_{63}$ and $D_{64}$. The sequencing of the peptide $54-71$ by MS/MS was conducted to discriminate if one specific residue $\left(D_{63}\right.$ or $\left.D_{64}\right)$ or the two residues underwent the water loss during the dry heating. 

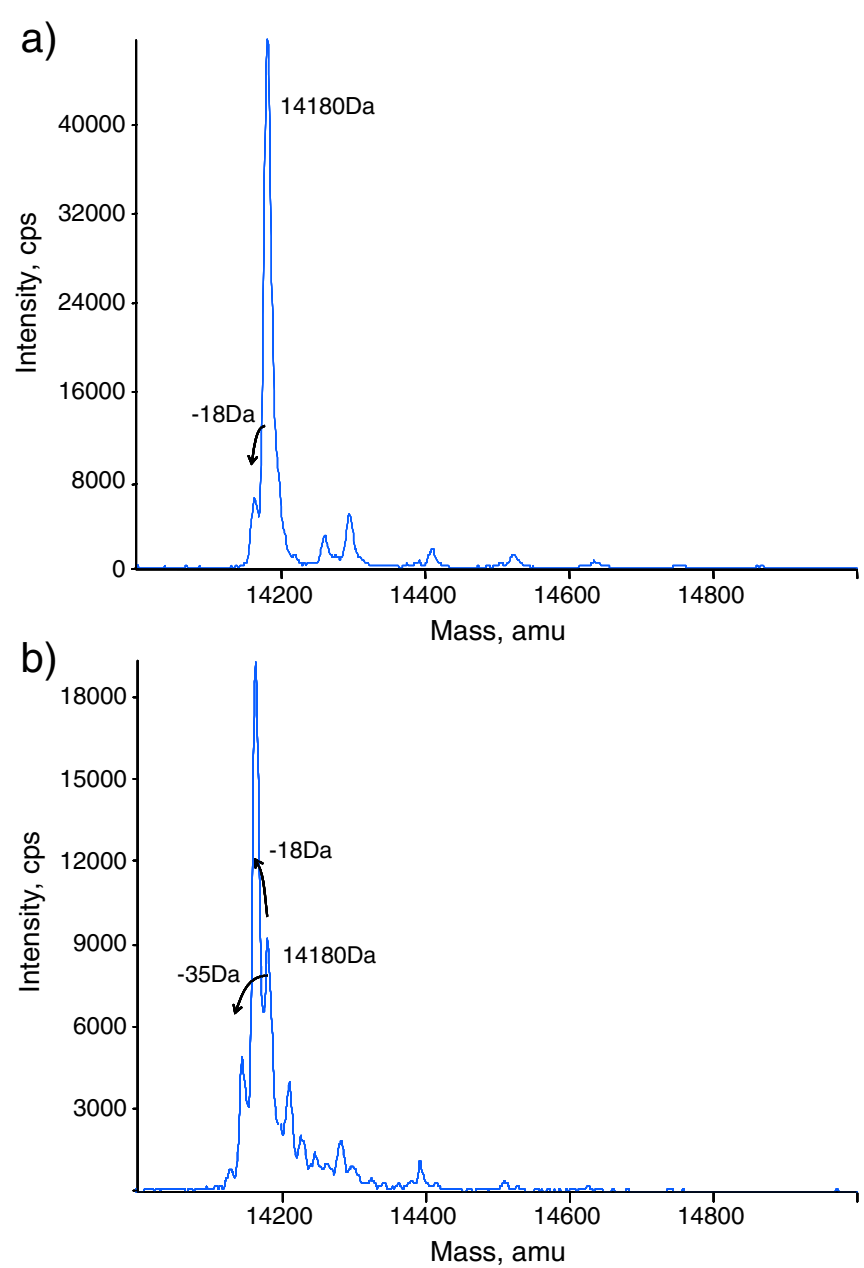

Fig. 4. Mass spectrum of $\alpha$-lactalbumin before (a) and after $24 \mathrm{~h}$ (b) of dry heating treatment at $100{ }^{\circ} \mathrm{C}$ showing the formation of non-native monomers exhibiting mass loss of -18 Da or -35 Da.

The mass of the resulting fragments identified by the MS/MS and corresponding to the fragmentation of peptide bonds either at position $b$ or at position $y$ has been shown in Table 1. The presence of the fragment of 880.47 Da was indicative of the release of a water molecule from

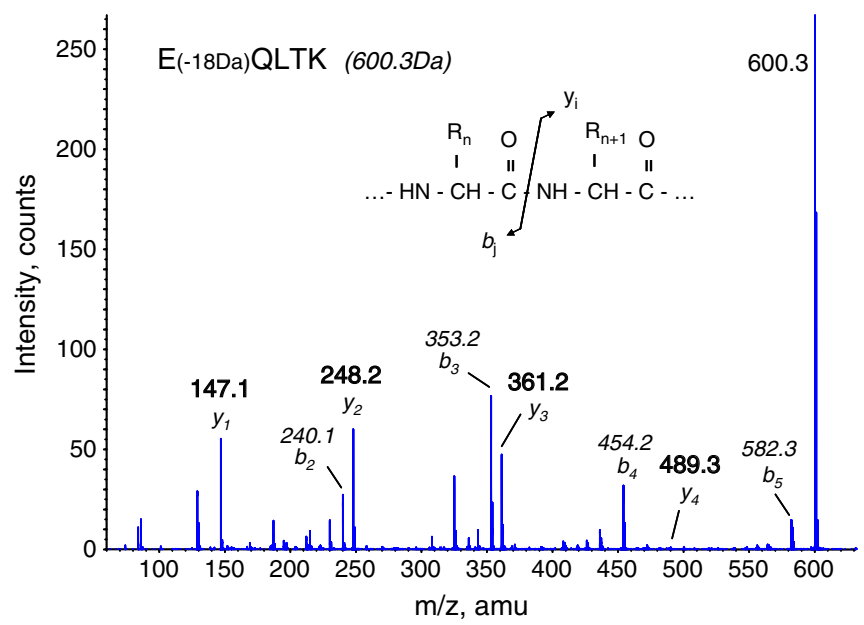

Fig. 5. $\mathrm{N}$-terminal $\alpha$-lactalbumin tryptic peptide sequencing by tandem mass spectrometry. Mass of the peptide EQLTK exhibiting a $\mathrm{N}$ terminal pyroglutamic acid is $600.3 \mathrm{Da} . b_{\mathrm{j}}$ and $y_{\mathrm{i}}$ represent the cleavage of the peptide bond after the amino acid number $\mathrm{i}$ (from $\mathrm{C}$ terminal amino acid of the peptide) or $\mathrm{j}$ (from the $\mathrm{N}$ terminal amino acid of the peptide) in the peptide sequence. the residue $\mathrm{D}_{64}$ (Fig. 7). A fragment with a mass of $898.4 \mathrm{Da}$, which would have indicated a release of a water molecule from $D_{63}$, was not detected during the MS/MS fragmentation process.

\section{Discussion}

The dry heating at $\mathrm{pH} 6.5$ induced specific chemical modifications in the primary sequence of whey proteins but changes in their secondary and tertiary structures were weak and the aggregation reactions were limited. In its native form, $\beta$ - $\mathrm{Lg}$ exists as a mixture of dimers and monomers in fast equilibrium and consequently is eluted on HP-GPC at intermediate retention time between dimer and monomer (Reithel \& Kelly, 1971). Dry heating trapped a fraction of $\beta$ - $\mathrm{Lg}$ molecules as monomers that were unable to reform the native dimer/monomer equilibrium of $\beta$ - Lg. The $\beta$ - $\operatorname{Lg}$ monomers exhibiting similar shift in retention time on HP-GPC were previously observed after heating in solution, and were characterized by non-native disulfide bonds (Croguennec, Bouhallab, Molle, O'Kennedy, \& Mehra, 2003; Surroca, Haverkamp, \& Heck, 2002). Compared to the previously reported non-native monomers that were insoluble at the protein pI (Croguennec et al., 2003), the $\beta$ - $\mathrm{Lg}$ monomers trapped during the dry heating preserved their solubility, which might indicate different structural changes. Unfortunately, structural changes responsible for this particular behavior are not identified yet.

Protein monomers exhibiting a molecular mass difference with native protein (called non-native monomers in the following) were more abundant in the dry-heated $\alpha$-La, i.e. $73 \%$ of non-aggregated proteins against only $18 \%$ for $\beta$-Lg. The non-native monomers of $\alpha$-La exhibited stronger interactions with the reverse phase gel matrix suggesting that their hydrophobic patches are more accessible than it might have been the case for native $\alpha$-La. This is in agreement with previous findings of Ibrahim et al. (1993). Mass spectrometry indicated that the non-native monomers of $\alpha$-La were characterized by one or two irreversible losses of water molecule per protein molecule. These dehydrations were associated either with the cyclization of the $\mathrm{N}$-terminal glutamic acid or the internal cyclic imide formation.

The N-terminal cyclization of glutamic acid (E) of $\alpha$-La leads to the formation of pyroglutamic acid (Fig. 8a) (Liu, Gaza-Bulseco, \& Sun, 2006). Although non-enzymatic formation of pyroglutamic residue from $\mathrm{E}$ is less common than from $\mathrm{Q}$, it has already been reported for several proteins (Liu et al., 2006). It results from an attack of the deprotonated $\alpha$-amino group on the side chain carbonyl group of the N-term glutamic acid. The reaction occurs spontaneously at room temperature (Dick, Kim, Qiu, \& Cheng, 2007) but is accelerated at elevated temperatures (Park, Lee, \& Ryu, 2001; Yu et al., 2006). This reaction has already been described for $\alpha$-La after heating in solution (Meltretter, Seeber, Humeny, Becker, \& Pischetsrieder, 2007). When comparing to the above study, the frequency of occurrence of pyroglutamic acid was much higher during the heat treatment in dry state than in solution, probably due to favorable mass balance.

The formation of an internal cyclic imide (Fig. 8b) results from the attack of the $\alpha$-amino group of $n+1$ residue on the side chain carbonyl group of aspartic acid, D or glutamic acid, E (Geiger \& Clarke, 1987). The formation of the internal cyclic imide was demonstrated for at least a fraction of non-native $\alpha$-La molecules exhibiting two modifications after the dry heating. Basically, the rate of the cyclic imide formation from $\mathrm{D}$ is low compared to the rate of formation of the pyroglutamic acid and the cyclic imide stability is limited at neutral pH (Desfougeres et al., 2010; Xie \& Schowen, 1999). The cyclic imide formation is favored if a $G$ residue is located at position (D or E) + 1 (Geiger \& Clarke, 1987), even if other amino acids have also been identified (Desfougeres et al., 2010). This reaction also requires the involved residues to be located in a poorly structured part of the protein. In $\alpha$-La, the $D_{64}$ is not involved in a repetitive secondary structure and therefore provides an ideal sequence for a cyclic imide formation. 


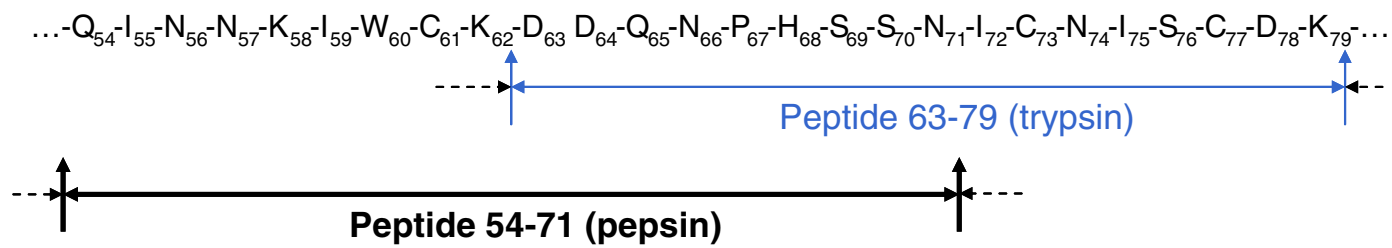

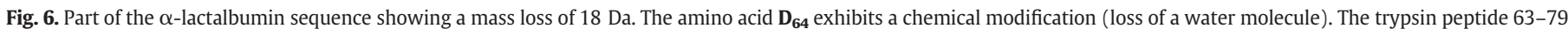

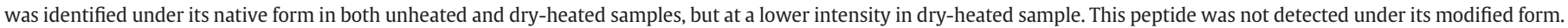

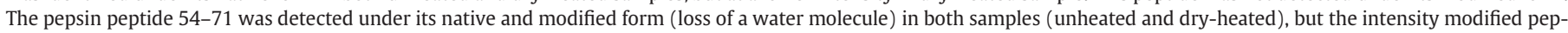
tide was enhanced after dry heating (more than 5 times).

Interestingly, no other site of modification was detected for $\alpha$-La suggesting that the identified sites of modification are rather specific. This specificity could also explain that a fraction of the $\alpha$-La molecules exhibited a mass loss of 18 Da before the dry heating treatment. For comparison, $\beta$ - Lg was also analyzed by mass spectrometry but the non-native monomers of $\beta$ - $\mathrm{Lg}$ exhibiting that mass losses of $18 \mathrm{Da}$ was not observed before and its occurrence was very low after dry heating (data not shown). Given the low amount of modified $\beta$ - $\mathrm{Lg}$, the identification of modified amino-acids was not further investigated.

Apart from the structural changes and the chemical modifications described above, the dry-heated samples of whey proteins also contained some aggregates. The aggregates were limited to about $30 \%$ of the proteins. They were mainly of small sizes (mainly dimers and oligomers). The limited size of the aggregates results probably from the very low translational motion of the proteins in powders. Consequently cross-linking reactions are restricted to proteins in very close vicinity (diffusion limited). In addition, it is possible that the formation of intermolecular cross-links between reactive groups requires specific orientation of the proteins. Another hypothesis is that the surface properties of the proteins are not favorable for the aggregation to occur, which may explain the presence of mainly small aggregates. The aggregates were soluble and were covalently linked with some intermolecular bonds resistant to reduction. The same kind of resistant intermolecular cross-links has already been observed in dry-heated whey proteins (Enomoto et al., 2009; Gulzar, Bouhallab, Jeantet, Schuck, \& Croguennec, 2011; Li, Enomoto, Ohki, Ohtomo, \& Aoki, 2005) and egg white proteins (Kato et al., 1989; Watanabe, Xu, \& Shimoyamada, 1999). The most prevalent intermolecular cross-links resistant to reduction are isopeptide bonds and other cross-links that involve a transient dehydroalanine resulting from the $\beta$-elimination of

Table 1

Mass of the $b_{\mathrm{i}}$ and $y_{\mathrm{j}}$ fragments of the peptic peptide $54-71$ sequenced by tandem mass spectrometry.

\begin{tabular}{llc}
\hline Residue & Fragment resulting from: & \\
\cline { 2 - 3 } & $b_{\mathrm{j}}$ cleavage & $y_{\mathrm{i}}$ cleavage \\
\hline $\mathrm{Q}_{54}$ & 129.07 & \\
$\mathrm{I}_{55}$ & 242.15 & \\
$\mathrm{~N}_{56}$ & 356.19 & \\
$\mathrm{~N}_{57}$ & 470.24 & \\
$\mathrm{~K}_{58}$ & 598.33 & \\
$\mathrm{I}_{59}$ & 711.42 & 1412.56 \\
$\mathrm{~W}_{60}$ & & 1226.52 \\
$\mathrm{C}_{61}$ & & 1123.51 \\
$\mathrm{~K}_{62}$ & & 995.39 \\
$\mathrm{D}_{63}$ & & $\mathbf{8 8 0 . 4 7}$ \\
$\mathrm{D}_{64} \mathbf{1 8}$ Da & & 783.35 \\
$\mathrm{Q}_{65}$ & & 655.28 \\
$\mathrm{~N}_{66}$ & & 541.25 \\
$\mathrm{P}_{67}$ & & 444.18 \\
$\mathrm{H}_{68}$ & & 307.12 \\
$\mathrm{~S}_{69}$ & & 220.09 \\
$\mathrm{~S}_{70}$ & & 133.06 \\
$\mathrm{~N}_{71}$ & & \\
\hline
\end{tabular}

In bold, the modified amino acid. serine and threonine residues (Gerrard, 2002). The isopeptide bonds and other cross-links that involve a transient dehydroalanine are prevalent after a dry heating treatment under basic $\mathrm{pH}$ conditions. Since such cross-links require the release of one molecule of water, it is not surprising that their occurrence is increased in a low water content medium due to a favorable mass balance. In addition to the intermolecular cross-links resistant to a reducing agent, both dry-heated $\beta$-Lg and $\alpha$-La samples contained some oligomers that were joined together by disulfide bonds, which is in accordance with our previous work on WPI (Gulzar et al., 2011). The $\beta$-Lg contains one sulfhydryl per molecule in its structure, which may provoke both oxidation and sulfhydryl/disulfide interchange reactions. Such intermolecular cross-links were already observed in unheated $\beta$ - Lg samples indicating that they are able to form during protein purification or storage. By increasing molecular motion, dry heating may activate the formation of intermolecular disulfide bonds. The formation of the disulfide-linked oligomers was also observed for $\alpha$-La, which does not contain free sulfhydryl group. Although the presence of a trace of $\beta$ - $\operatorname{Lg}$ in $\alpha$-La samples may initiate the sulfhydryl/disulfide interchange reactions leading to the formation of covalent $\alpha$-La oligomers, the formation of disulfide bonds was also observed after heating $\beta$-Lg-free samples of $\alpha$-La in solution (Doi, Tokuyama, Kuo, Ibuki, \& Kanamori, 1983; Hong \& Creamer, 2002; McGuffey, Epting, Kelly, \& Foegeding, 2005) and in dry state (Enomoto et al., 2009). At elevated temperatures $\left(\geq 95{ }^{\circ} \mathrm{C}\right)$ a disruption of one or more disulfide bonds in the structure of $\alpha$-La may release free sulfhydryl groups that can initiate intermolecular sulfhydryl/disulfide interchange or oxidation reactions resulting in the formation of disulfide-linked oligomers (Chaplin \& Lyster, 1986). The increased accessibility of $\alpha$-La hydrophobic patches after the dry heating may also be explained by disruption of disulfide bonds.

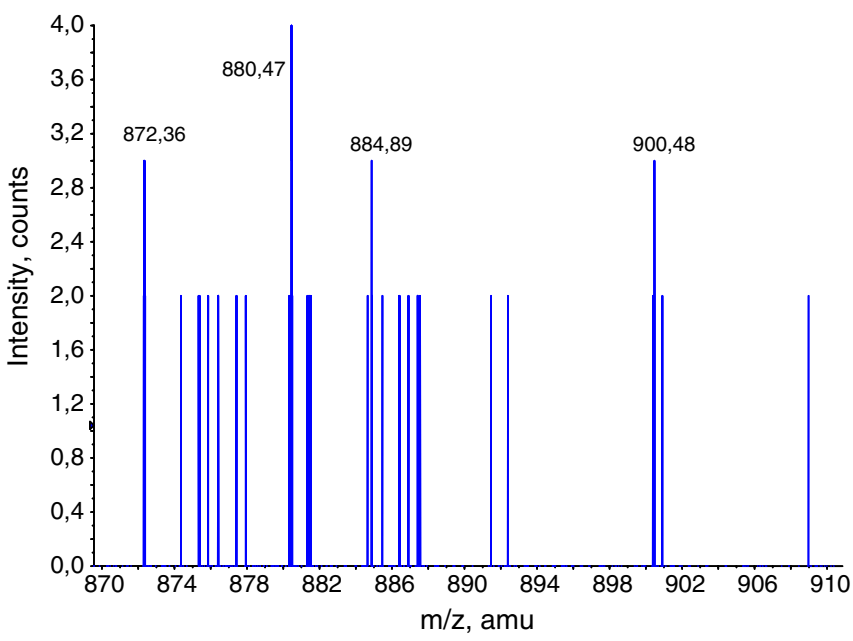

Fig. 7. Zoom on the $870-910$ amu region of the $\alpha$-lactalbumin pepsin peptide $54-71$ sequenced by tandem mass spectrometry. The presence of a mass at $880.47 \mathrm{amu}$ and the absence of mass at 898.4 amu indicate that the $D_{64}$ only undergoes dehydration during dry heating. 
a)

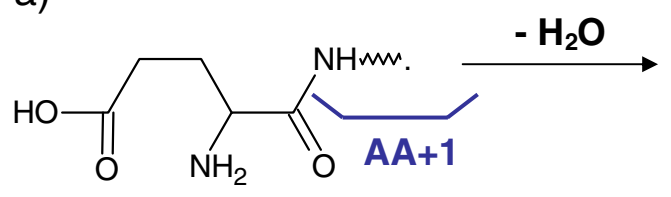

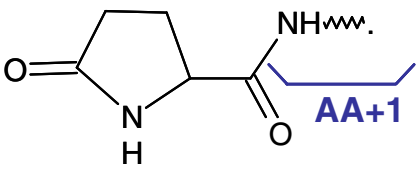

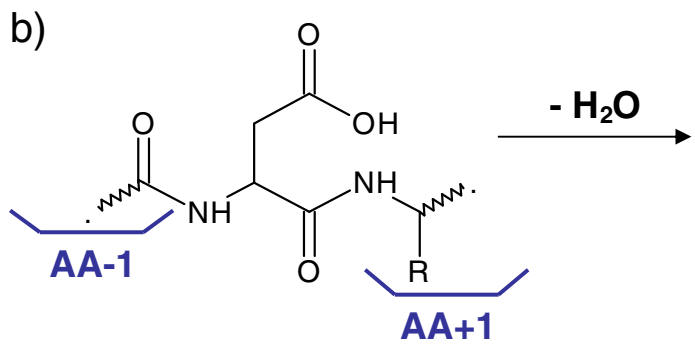

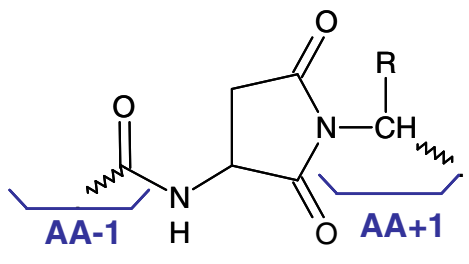

Fig. 8. Chemical structure of (a) the N-Terminal pyroglutamic acid resulting from the cyclization of the N-terminal glutamic acid of $\alpha$-lactalbumin, (b) a cyclic imide resulting from the cyclization of an internal aspartyl residue.

\section{Conclusion}

The process of the dry-heat denaturation/aggregation was limited to dimers and small oligomers in purified samples of the proteins analyzed ( $\beta$ - $\mathrm{Lg}$ and $\alpha$-La). In these molecular entities, proteins were joined together by disulfide bonds and covalent bonds other than disulfide bonds. The characteristic of a large amount of $\alpha$-La molecules was an irreversible mass loss of $18 \mathrm{Da}$ from the glutamic acid residue at the $\mathrm{N}$-terminal position. The N-terminal glutamic acid is reactive and spontaneously evolves into pyroglutamic acid during the course of dry heating. In addition, dry heating induces the formation of a specific internal cyclic imide at position $\mathrm{D}_{64}$. Such reactions are favored for proteins in a powder form due to favorable mass balance, but further investigations of their $a_{w}$-dependence would be beneficial for manufacturers of dry-heated protein ingredients. The specificity of these reactions combined with a low level of aggregation could explain the specific functional properties (foaming, emulsifying, and gelling) of the dry-heated proteins. Hence, the control of the functional properties of the dryheated proteins requires detailed determination of the changes induced in protein structures. In addition, evolutions in the functional properties of protein ingredients during storage are sometimes observed although the secondary and tertiary structures of the proteins seem to remain unchanged. Even if the exact functional properties of chemically modified protein monomers are still unknown and are currently under investigation, it is likely that the evolution of the functional properties of protein powders during long-term storage are linked to very specific modifications such as those highlighted in this study.

\section{Acknowledgment}

We are highly grateful to the Higher Education Commission of Pakistan (HEC) and INRA, France, for the financial support of this research project. We thank Dr Adam Macierzanka for the English corrections in the manuscript.

\section{Appendix A. Supplementary data}

Supplementary data to this article can be found online at http:// dx.doi.org/10.1016/j.foodres.2013.02.025.

\section{References}

Aoki, T., Kitahata, K., Fukumoto, T., Sugimoto, Y., Ibrahim, H. R., Kimura, T., et al. (1997). Improvement of functional properties of beta-lactoglobulin by conjugation with glucose-6-phosphate through the Maillard reaction. Food Research International, 30, 401-406.

Chaplin, L. C., \& Lyster, R. L. J. (1986). Irreversible heat denaturation of bovine alpha-lactalbumin. The Journal of Dairy Research, 53, 249-258.

Croguennec, T., Bouhallab, S., Molle, D., O'Kennedy, B. T., \& Mehra, R. (2003). Stable monomeric intermediate with exposed Cys-119 is formed during heat denaturation of beta-lactoglobulin. Biochemical and Biophysical Research Communications, 301, 465-471.

Desfougeres, Y., Jardin, J. Lechevalier, V., Pezennec, S., \& Nau, F. (2010). Succinimidyl residue formation in hen egg-white lysozyme favors the formation of intermolecular covalent bonds without affecting its tertiary structure. Biomacromolecules, 12, 156-166.

Desfougeres, Y., Lechevalier, V., Pezennec, S., Artzner, F., \& Nau, F. (2008). Dry-heating makes hen egg white lysozyme an efficient foaming agent and enables its bulk aggregation. Journal of Agricultural and Food Chemistry, 56, 5120-5128.

Dick, L. W., Kim, C., Qiu, D., \& Cheng, K. -C. (2007). Determination of the origin of the $\mathrm{N}$-terminal pyro-glutamate variation in monoclonal antibodies using model peptides. Biotechnology and Bioengineering, 97(3), 544-553.

Doi, H., Tokuyama, T., Kuo, F. H., Ibuki, F., \& Kanamori, M. (1983). Heat-induced complex-formation between K-casein and alpha-lactalbumin. Agricultural and Biological Chemistry, 47, 2817-2824.

Enomoto, H., Hayashi, Y., Li, C. P., Ohki, S., Ohtomo, H., Shiokawa, M., et al. (2009). Glycation and phosphorylation of alpha-lactalbumin by dry heating: Effect on protein structure and physiological functions. Journal of Dairy Science, 92, 3057-3068.

Geiger, T., \& Clarke, S. (1987). Deamidation, isomerization, and racemization at asparaginyl and aspartyl residues in peptides-Succinimide-linked reactions that contribute to protein-degradation. Journal of Biological Chemistry, 262, 785-794.

Gerrard, J. A. (2002). Protein-protein crosslinking in food: Methods, consequences, applications. Trends in Food Science \& Technology, 13, 391-399.

Gulzar, M., Bouhallab, S., Jeantet, R., Schuck, P., \& Croguennec, T. (2011). Influence of pH on the dry heat-induced denaturation/aggregation of whey proteins. Food Chemistry, 129, 110-116.

Gulzar, M., Lechevalier, V., Bouhallab, S., \& Croguennec, T. (2012). The physicochemical parameters during dry-heating strongly influence the gelling properties of whey proteins. Journal of Food Engineering, 112(4), 296-303.

Hong, Y. H., \& Creamer, L. K. (2002). Changed protein structures of bovine [beta]-lactoglobulin B and [alpha]-lactalbumin as a consequence of heat treatment. International Dairy Journal, 12, 345-359.

Ibrahim, H. R., Kobayashi, K., \& Kato, A. (1993). Improvement of the surface functional-properties of beta-lactoglobulin and alpha-lactalbumin by heating in a dry state. Bioscience, Biotechnology, and Biochemistry, 57, 1549-1552.

Kato, A., Ibrahim, H. R., Watanabe, H., Honma, K., \& Kobayashi, K. (1989). New approach to improve the gelling and surface functional-properties of dried egg-white by heating in dry state. Journal of Agricultural and Food Chemistry, 37, 433-437.

Kato, A., Ibrahim, H. R., Watanabe, H., Honma, K., \& Kobayashi, K. (1990). Structural and gelling properties of dry-heating egg-white proteins. Journal of Agricultural and Food Chemistry, 38, 32-37.

Laemmli, U. K. (1970). Cleavage of structural proteins during the assembly of the head of bacteriophage T4. Nature, 227, 680-685.

Li, C. P., Enomoto, H., Ohki, S., Ohtomo, H., \& Aoki, T. (2005). Improvement of functional properties of whey protein isolate through glycation and phosphorylation by dry heating. Journal of Dairy Science, 88, 4137-4145.

Liu, H., Gaza-Bulseco, G., \& Sun, J. (2006). Characterization of the stability of a fully human monoclonal IgG after prolonged incubation at elevated temperature. Journal of Chromatography B, 837, 35-43.

Matsudomi, N., Ishimura, Y., \& Kato, A. (1991). Improvement of gelling properties of ovalbumin by heating in dry state. Agricultural and Biological Chemistry, 55, 879-881.

Matsudomi, N., Takahashi, H., \& Miyata, T. (2001). Some structural properties of ovalbumin heated at $80{ }^{\circ} \mathrm{C}$ in the dry state. Food Research International, 34(2-3), 229-235. 
McGuffey, M. K., Epting, K. L., Kelly, R. M., \& Foegeding, E. A. (2005). Denaturation and aggregation of three $\alpha$-lactalbumin preparations at neutral $\mathrm{pH}$. Journal of Agricultural and Food Chemistry, 53, 3182-3190.

Meltretter, J., Seeber, S., Humeny, A., Becker, C. M., \& Pischetsrieder, M. (2007). Site-specific formation of Maillard, oxidation, and condensation products from whey proteins during reaction with lactose. Journal of Agricultural and Food Chemistry, 55, 6096-6103.

Mine, Y. (1996). Effect of pH during the dry heating on the gelling properties of egg white proteins. Food Research International, 29, 155-161.

Mine, Y. (1997). Effect of dry heat and mild alkaline treatment on functional properties of egg white proteins. Journal of Agricultural and Food Chemistry, 45, 2924-2928.

Park, C. B., Lee, S. B., \& Ryu, D. D. Y. (2001). L-pyroglutamate spontaneously formed from L-glutamate inhibits growth of the hyperthermophilic archaeon Sulfolobus solfataricus. Applied and Environmental Microbiology, 67, 3650-3654.
Reithel, F. J., \& Kelly, M. J. (1971). Thermodynamic analysis of the monomer-dimer association of .beta.-lactoglobulin A at the isoelectric point. Biochemistry, 10, 2639-2644.

Surroca, Y., Haverkamp, J., \& Heck, A. J. R. (2002). Towards the understanding of molecular mechanisms in the early stages of heat-induced aggregation of beta-lactoglobulin $\mathrm{AB}$ Journal of Chromatography. A, 970, 275-285.

Watanabe, K., Xu, J. Q., \& Shimoyamada, M. (1999). Inhibiting effects of egg white dry-heated at 120 degrees $C$ on heat aggregation and coagulation of egg white and characteristics of dry-heated egg white. Journal of Agricultural and Food Chemistry, 47, 4083-4088.

Xie, M., \& Schowen, R. L. (1999). Secondary structure and protein deamidation. Journal of Pharmaceutical Sciences, 88, 8-13.

Yu, L., Vizel, A., Huff, M. B., Young, M., Remmele, R. L., \& He, B. (2006). Investigation of $\mathrm{N}$-terminal glutamate cyclization of recombinant monoclonal antibody in formulation development. Journal of Pharmaceutical and Biomedical Analysis, 42, 455-463. 